\title{
Cytotoxic Effect of Samarium(III)-Based Complexes: Synthesis, Characterization and Photoluminescence Properties
}

\section{AHMET ORAL SARIOGLU ( $\sim$ aoralsarioglu@gmail.com )}

Gaziantep University: Gaziantep Universitesi https://orcid.org/0000-0001-7787-7968

demet taşdemir kahraman

Gaziantep Universitesi Tip Fakultesi

Aysegül köse

Kahramanmaras Istiklal Universitesi

mehmet sönmez

Gaziantep University: Gaziantep Universitesi

\section{Research Article}

Keywords: Lanthanide complex, Samarium, Photoluminescence, Cytotoxic effect

Posted Date: January 19th, 2022

DOI: https://doi.org/10.21203/rs.3.rs-1253776/v1

License: @ (i) This work is licensed under a Creative Commons Attribution 4.0 International License.

Read Full License 


\section{Abstract}

Three new homoleptic six-coordinate Sm(III) complexes have been synthesized from diketone ligand with different substituent groups. The structural properties of these compounds have been investigated using elemental analysis, UV-Vis, and FT-IR approaches. Then, their photoluminescence properties of the synthesized Sm complexes have been examined.

Also, the cytotoxic activities of the complexes have been studied against to human epidermoid carcinoma cell (HTB-54) and normal bronchus epithelial cell (BEAS-2B). According to result, the [Sm(MPBP-1,3PPon) $\left.\left.)_{3}\right] \cdot \mathrm{H}_{2} \mathrm{O}\right)\left(\mathrm{IC}_{50}: 11.05 \mu \mathrm{M}\right)$ complex was more active than [Sm(BMP-1,3PPon) $\left.{ }_{3}\right] \cdot 2 \mathrm{H}_{2} \mathrm{O}$ $\left(\mathrm{IC}_{50}: 58.64 \mu \mathrm{M}\right)$ and $\left[\mathrm{Sm}\left(\mathrm{BCP}_{-}{ }^{1,3}{ }^{3} \mathrm{PPon}\right)_{3}\right] \cdot \mathrm{H}_{2} \mathrm{O}\left(\mathrm{IC}_{50}:>500 \mu \mathrm{M}\right)$ complexes. Otherwise it was no effect on normal cell (BEAS-2B). This result shows that complex [Sm(MPBP- $\left.{ }^{1,3}{ }^{2} P \mathrm{Sn}_{3}\right)_{3} \cdot \mathrm{H}_{2} \mathrm{O}$ ) has the potential to be the ideal chemotherapeutic drug.

\section{Introduction}

The luminescence characteristics of rare earth metal complexes with various organic ligands have recently received a lot of attention. There are many studies in the literature on the synthesis and photophysical characteristics of lanthanide complexes with different substituents of $\beta$-diketone ligands. [1].

The lanthanide complexes have different applications such as light-emitting diodes (LEDs) [2-4], lasers [5-8], sensors [9-11], luminescent probes in biomedical [12-16], solar energy conversion [17, 18], single molecule magnets [19-24], superconducting materials [25-30] etc.

Ln(III) ions show distinct photophysical features, including intra-configurational $4 f-4 f$ transitions, narrow emission bands, a significant Stoke's shift, a long luminescence decay time, and strong luminescence generated by electron transitions between long-time emission spectra. [31-33].

The lanthanide ions are one of the essential components because of their spectroscopic and magnetic properties in the preparation of new materials and as suitable probes in studies of biological systems. [34].

Lung cancer is described as the deadliest type of cancer that causes 1.76 million deaths out of 2.09 million cases in the World [35]. There are two commonly known groups of lung cancers: small cell and non-small cell lung cancer. Epidermoid cancer, also called squamous cancer, is a type of non-small cell lung cancer [36]. Non-small cell lung cancer (NSCLC) is the most common group of lung cancer, occurring in eight or nine out of ten cases. Despite the use of chemotherapy, radiotherapy and immunotherapy, the 5 -year survival rate is $15 \%$ when all cases are included. Unfortunately, the chemotherapy drugs such as cisplatin-based cause side effects on renal [37], liver [38] cells after treatment. For years, especially pharmacology and chemist researchers have been synthesized hundreds of new potential anti-cancer compounds to reduce the toxic effect. 
We present the synthesis, photophysical characteristics and cytotoxic impact of new Sm(III) complexes in this study. The Sm(III) complexes were synthesized from the reaction of 1-( 4-methoxyphenyl)-3-(4-tertbutylphenyl)-1,3-propanedione (MPBP-1,3PPon), 1,3-bis(4-methoxyphenyl )-1,3-propanedione (BMP1,3PPon), 1,3-bis(4-chlorophenyl)-1,3-propanedione (BCP-1,3PPon). The photoluminescence features of $\mathrm{Sm}$ (III) complexes were examined in DMF. On the other hand, we evaluated anti-cancer effects of [Sm(MPBP-1,3PPon) $\left.\left.)_{3}\right] \cdot \mathrm{H}_{2} \mathrm{O}\right),\left[\mathrm{Sm}\left(\mathrm{BMP}_{-}{ }^{1,3}{ }^{3} \mathrm{PPon}\right)_{3}\right] \cdot 2 \mathrm{H}_{2} \mathrm{O}$ and [Sm(BCP-1,3PPon) $\left.{ }_{3}\right] \cdot \mathrm{H}_{2} \mathrm{O}$ complexes on epidermoid cancer cell lines (HTB-54).

\section{Experimantel}

\section{Materials and instruments}

All the materials were acquired with a stated purity of $99 \%$ from Sigma-Aldrich Chemical and Merck Company and utilized without additional purification. On a PG Instruments T80 + UV/Vis spectrometer, the UV-Vis spectrums were recorded from a $1 \times 10^{-3} \mathrm{M}$ solution of the compounds in DMF, DMSO and DCM from 800 to $190 \mathrm{~nm}$. The IR ATR spectrum was produced using the Attenuated Total Reflectance (ATR) model on a Perkin Elmer FT-IR spectrometer between $4000-400 \mathrm{~cm}^{-1}$ at spectral intervals of $2 \mathrm{~cm}^{-1}$. Elemental analyses of the substances were performed using a Thermo Scientific Flash $2000 \mathrm{CHNS}$ analyzer. The compounds excitation/emission spectra were measured with a Perkin Elmer LS55 luminescence spectrometer.

\section{Preparation of Sm(III) complexes}

A solution of MPBP-1,3PPon (232 mg, $0.75 \mathrm{mmol}$ ), BMP-1,3PPon (213 mg, $0.75 \mathrm{mmol}$ ), BCP-1,3PPon (220 $\mathrm{mg}, 0.75 \mathrm{mmol})$ in dry ethanol $(25 \mathrm{ml})$ was added dropwise into a solution of $\mathrm{SmCl}_{3}(64 \mathrm{mg}, 0,25 \mathrm{mmol})$ in absolute ethanol $(10 \mathrm{ml})$ under stirring at $75^{\circ} \mathrm{C}$ for $5 \mathrm{~h}$. Then, the $\mathrm{pH}$ of the reaction mixture was adjusted to around 6 using $\mathrm{NaOH}(\mathrm{aq})$. The yellow powder was filtered off, washed with ethanol and dried in vacuo for 48 hours.

[Sm(MPBP-1,3PPon) $\left.{ }_{3}\right] \cdot H_{2} \mathrm{O}$ (Fig. S1): Yield: $45 \%, \mathrm{mp}: 245-248{ }^{\circ} \mathrm{C}$, UV vis (DMF) $\lambda_{\max } \mathrm{nm}$ (log $\varepsilon$ ): 360 (1.697), 268 (0.825). IR $\vee$ ATR( $\left.\mathrm{cm}^{-1}\right)$ : 3044 (br,C-H arm); 2956 (aliphaticcarbon); 1738 (str, C=0); 1595 (m, enolic $\mathrm{C}=\mathrm{C}$ ); 1251 (methoxy $\mathrm{C}-\mathrm{O}-\mathrm{C}) ; 504(\mathrm{Sm}-0)$. Chemical Formula: $\mathrm{C}_{60} \mathrm{H}_{65} \mathrm{O}_{10} \mathrm{Sm}$; Molecular Weight: 1186,58; Anal.Calcd.For $\mathrm{C}_{60} \mathrm{H}_{65} \mathrm{O}_{10} \mathrm{Sm}(\%)$ : C, 65.72; $\mathrm{H}, 5.97$. Found (\%): C, 65.41; $\mathrm{H}, 5.65$.

[Sm(BMP-1,3PPon) $\left.{ }_{3}\right] \cdot 2 \mathrm{H}_{2}$ O (Fig. S2): Yield: $77 \%, \mathrm{mp:} 238-241^{\circ} \mathrm{C}$, UV vis (DMF) $\lambda_{\max } \mathrm{nm}(\log \varepsilon): 365$ (2.102), 268 (0.959). IR $\vee$ ATR $\left(\mathrm{cm}^{-1}\right)$ : 3066 (br,C-H arm); 2958 (aliphaticcarbon); 1738 (str, C=0); 1597 (m, enolic $\mathrm{C}=\mathrm{C}$ ); 1255 (methoxy $\mathrm{C}-0-\mathrm{C}) ; 465(\mathrm{Sm}-0)$. Chemical Formula: $\mathrm{C}_{51} \mathrm{H}_{49} \mathrm{O}_{14} \mathrm{Sm}$; Molecular Weight: 1036,28; Anal.Calcd.For $\mathrm{C}_{51} \mathrm{H}_{49} \mathrm{O}_{14} \mathrm{Sm}(\%)$ : C, 59.11; $\mathrm{H}, 4.77$. Found (\%): C, 59.06; $\mathrm{H}, 4.34$. 
[Sm(BCP-1,3PPon) $\left.{ }_{3}\right] \cdot H_{2} O$ (Fig. S3): Yield: $41 \%, \mathrm{mp:} 261-264^{\circ} \mathrm{C}$, UV vis (DMF) $\lambda_{\max } \mathrm{nm}$ (log $\varepsilon$ ): 358 (1.505), 268 (0.994). IR $\vee$ ATR $\left(\mathrm{cm}^{-1}\right)$ : 3069 (br,C-H arm); 2911 (aliphaticcarbon); 1737 (str, C=0); 1587 (m, enolic $\mathrm{C}=\mathrm{C}) ; 483$ (Sm-0). Chemical Formula: $\mathrm{C}_{45} \mathrm{H}_{29} \mathrm{Cl}_{6} \mathrm{O}_{7} \mathrm{Sm}$; Molecular Weight: 1044,79; Anal.Calcd.For $\mathrm{C}_{45} \mathrm{H}_{29} \mathrm{Cl}_{6} \mathrm{Sm}(\%)$ : C, 51.73; $\mathrm{H}, 2.80$. Found (\%): C, 51.54; $\mathrm{H}, 2.71$.

\section{Cytotoxic Result:}

The effects of [Sm(MPBP-1,3PPon) $\left.\left.{ }_{3}\right] \cdot \mathrm{H}_{2} \mathrm{O}\right)$ and [Sm(BMP-1,3PPon) $\left.{ }_{3}\right] \cdot 2 \mathrm{H}_{2} \mathrm{O}$ on all concentrations $(31,62$, $125,250,500 \mu \mathrm{M})$ were statistically significant when compared with DMSO in HTB-54 cells ( $p<0.001)$. $\left[\mathrm{Sm}\left(\mathrm{BCP}_{-}{ }^{1,3} \mathrm{PPon}\right)_{3}\right] \cdot \mathrm{H}_{2} \mathrm{O}$ complexes has no effect on cancer cells. For these reason, we were not studied on BEAS-2B for toxic experiment. Inhibitory concentrations of [Sm(MPBP-1,3PPon) $\left.{ }_{3}\right] \cdot \mathrm{H}_{2} \mathrm{O}$ ) was determined as $11.05 \mu \mathrm{M}$ in HTB-54 cells. Similarly [Sm(BMP-1,3PPon) $\left.{ }_{3}\right] \cdot 2 \mathrm{H}_{2} \mathrm{O}$ was $58.64 \mu \mathrm{M}$. So $\left.\left[\mathrm{Sm}\left(\mathrm{MPBP}_{-}{ }^{1,3}{ }^{\mathrm{PPO}}\right)_{3}\right] \cdot \mathrm{H}_{2} \mathrm{O}\right)$ complex was better anti-cancer effect than [Sm(BMP-1,3PPon) $\left.{ }_{3}\right] \cdot 2 \mathrm{H}_{2} \mathrm{O}$ for cancer cells (Figure 2). In addition, [Sm(MPBP-1,3PPon) $\left.{ }_{3}\right] \cdot \mathrm{H}_{2} \mathrm{O}$ ) complex has no toxic effect on healty cell (BEAS-2B) so this compound is more suitable for ideal drug properties and has potential therapeutic agent (Figure 3).

\section{IR spectra}

Within the range of $4000-400 \mathrm{~cm}^{-1}$, the IR spectra of compounds were determined. The IR spectrums of the $\left[\mathrm{Sm}\left(\mathrm{MPBP}_{-}{ }^{1,3}{ }^{3} \mathrm{PPon}\right)_{3}\right] \cdot \mathrm{H}_{2} \mathrm{O}$ (Fig. S4), [Sm(BMP-1,3PPon) $\left.{ }_{3}\right] \cdot 2 \mathrm{H}_{2} \mathrm{O}$ (Fig. S5) and [Sm(BCP-

${ }^{1,3}$ PPon) $\left.{ }_{3}\right] \cdot \mathrm{H}_{2} \mathrm{O}$ (Fig. S6) complexes showed a weak broad absorption bands at 3044, 3066 and $3069 \mathrm{~cm}^{-}$

${ }^{1}$ assigned to the aromatic carbon $\mathrm{v}\left(\mathrm{C}^{3} / 4 \mathrm{H}\right)$ a stretching vibration [40], absorption bands at 2956, 2958 and $2911 \mathrm{~cm}^{-1}$ assigned to the aliphatic carbon $\mathrm{v}\left(\mathrm{C}^{3} / 4 \mathrm{H}\right)$ a stretching vibration [41], respectively. The strong characteristic vibration bands of the lanthanide complexes occurring at 1738 and $1737 \mathrm{~cm}^{-1}$ are due to carbonyl $v(C=0)[42,43]$. Also, the absorption bands observed at 1595,1597 and $1587 \mathrm{~cm}^{-1}$ belong to the enolic carbon $\mathrm{v}(\mathrm{C}=\mathrm{C})$ a stretching vibration [44] and absorption bands at 1251 and $1255 \mathrm{~cm}^{-1}$ belong to the methoxy groups $\mathrm{v}\left(\mathrm{C}^{3 / 4} \mathrm{O}^{3 / 4} \mathrm{C}\right)$ a stretching vibration, respectively. The results show that ligands can effectively coordinate with the $\mathrm{Sm}(\mathrm{III})$ ion.

\subsection{UV-Vis specta}

The UV-Vis spectra of Sm(III) complexes were obtained in the range of 190-1100 nm by using DMF, DMSO and DCM solvents and the corresponding spectra are presented in Figure 4-6. These bands found in the UV-Vis spectra of Sm(III) complexes at 360,365 , and $358 \mathrm{~nm}$ in the DMF solution are linked to the singlet-singlet $n-\pi^{\star}$ transition of enol groups. Furthermore, the $\pi-\pi^{\star}$ transition of phenyl rings and carbonyl groups is ascribed to the absorption maxima at $268 \mathrm{~nm}$. In DMSO, DMF, and DCM, the absorption wavelength of Sm(III) complexes was found to be slightly red shifted depending on the polarity of the solvent. [45-48]. 


\section{Photoluminescence properties}

The Sm(III) complexes of $\beta$-diketone derivatives showed a strong absorption band in the range of 300 $410 \mathrm{~nm}$ due to the $\pi-\pi^{\star}$ electronic transition of the conjugated $\beta$-diketone ligands. Therefore, we investigated the emission properties of the complexes in DMF $\left(10^{-5} \mathrm{M}\right)$ solution upon excitation at the maximum $\pi-\pi^{*}$ transition. The photoluminescence data are tabulated in Table 1. Emission spectra of $\left[\mathrm{Sm}\left(\mathrm{MPBP}_{-}{ }^{1,3} \mathrm{PPon}_{3}\right] \cdot \mathrm{H}_{2} \mathrm{O}\right)$, [Sm(BMP- $\left.{ }^{1,3}{ }^{3} \mathrm{SPon}_{3}\right] \cdot 2 \mathrm{H}_{2} \mathrm{O}$ and $\left[\mathrm{Sm}\left(\mathrm{BCP}_{-}{ }^{1,3} \mathrm{PPon}_{3}\right)_{3}\right] \cdot \mathrm{H}_{2} \mathrm{O}$ are given in Figure 7. The ligands in the complexes [Sm(MPBP- $\left.\left.\left.{ }^{1,3}{ }^{2} P_{0}\right)_{3}\right] \cdot \mathrm{H}_{2} \mathrm{O}\right)$, [Sm(BMP-1,3PPon) $\left.{ }_{3}\right] \cdot 2 \mathrm{H}_{2} \mathrm{O}$ and [Sm(BCP$\left.\left.{ }^{1,3} \mathrm{PPon}\right)_{3}\right] \cdot \mathrm{H}_{2} \mathrm{O}$ are similar differing in the substitute groups on the pheny rings. The substitute groups did not cause considerable shifts in the excitation spectra of the complexes. In DMF, the complexes showed several emission bands in the range of $400-810 \mathrm{~nm}$. All three complexes exhibited strong emission band in the range of 350-550 $\mathrm{nm}$ due to the ligand based emission ${ }^{1} \mathrm{~S}_{1} \rightarrow{ }^{1} \mathrm{~S}_{0}$. The substitute groups affect the ligand based emission maximums as well as intensities. The chloride groups has caused a considerable blue shift yet showed the highest emission intensity. This was observed for similar complexes reported by our group [40]. Complex [Sm(MPBP- ${ }^{1,3}$ PPon) $\left.{ }_{3}\right] \cdot \mathrm{H}_{2} \mathrm{O}$ ) shows $\mathrm{Sm}(\mathrm{III})$ based $\mathrm{f}$-f transitions at $578,586,634$, 729,768 and $824 \mathrm{~nm}$ and these emission bands were assigned to $f-f$ transition ${ }^{4} G_{5 / 2} \rightarrow{ }^{6} \mathrm{H}_{5 / 2}$ (forbidden transition), ${ }^{4} \mathrm{G}_{5 / 2} \rightarrow{ }^{6} \mathrm{H}_{7 / 2}$ (magnetic dipole transition), ${ }^{4} \mathrm{G}_{5 / 2} \rightarrow{ }^{6} \mathrm{H}_{9 / 2}$ (electric-dipole transition), ${ }^{4} \mathrm{G}_{5 / 2} \rightarrow$ ${ }^{6} \mathrm{H}^{11 / 2}$ (forbidden transition). The intensive emission band observed for electric-dipole transition $\left({ }^{4} \mathrm{G}_{5 / 2} \rightarrow\right.$ ${ }^{6} \mathrm{H}_{9 / 2}$ ) are associated with the coordination structures related to odd parity [49]. The coordination numbers and geometry around Sm(III) centre in those complexes are expected to be similar and the emission spectra due to the electric-dipole transition $\left({ }^{4} \mathrm{G}_{5 / 2} \rightarrow{ }^{6} \mathrm{H}_{9 / 2}\right)$ are almost identical in all complexes. In the spectra of [Sm(BCP-1,3PPon) $\left.)_{3}\right] \cdot \mathrm{H}_{2} \mathrm{O}^{4}{ }^{4} \mathrm{G}_{5 / 2} \rightarrow{ }^{6} \mathrm{H}_{9 / 2}$ (electric-dipole transition) and ${ }^{4} \mathrm{G}_{5 / 2} \rightarrow{ }^{6} \mathrm{H}^{11 / 2}$ (forbidden transition) transitions were observed at 638 and $761 \mathrm{~nm}$, respectively. The other $f-f$ transitions were not observed.

Table 1. Photoluminescence data for the compounds.

\begin{tabular}{|lll|}
\hline Compound & \multicolumn{2}{l|}{ Photoluminescence } \\
\cline { 2 - 3 } & Exc. & Em. \\
\hline$\left.\left.[\text { Sm(MPBP_-1,3PPon })_{3}\right] \cdot \mathrm{H}_{2} \mathrm{O}\right)$ & 308 & $426,578,586,634,729,768,824$ \\
\hline$\left[\mathrm{Sm}\left(\mathrm{BMP}^{1,3} \mathrm{PPon}\right)_{3}\right] \cdot 2 \mathrm{H}_{2} \mathrm{O}$ & 310 & $424,581,639,729,756,816$ \\
\hline$\left[\mathrm{Sm}\left(\mathrm{BCP}^{1}{ }^{1,3} \mathrm{PPon}\right)_{3}\right] \cdot \mathrm{H}_{2} \mathrm{O}$ & 310 & $408,638,761$ \\
\hline
\end{tabular}

\section{Results And Discussion}


Human epidermoid carcinoma cell (HTB-54) and normal bronchus epithelial cells (BEAS-2B) were cultured with different concentrations of the three complexes. The MTT test was used to determine cell viability. According to optical density results we calculated half maximal inhibitory concentration $\left(\mathrm{IC}_{50}\right)$.

\section{Cell Culture}

HTB-54 and BEAS-2B cells were grown 10\% fetal bovine serum (FBS; Gibco, USA) and \%1 antibiotic (Gibco, USA) supplemented in RPMI at $37^{\circ} \mathrm{C}, \% 5 \mathrm{CO} 2$ conditions.

\section{Chemical Exposure}

Cells were cultivated in 96 well plates $(2000$ cells $/ \mathrm{ml}$ ) for $48 \mathrm{~h}$. The culture medium contained $10 \%$ FBS and $\% 1$ antibiotic in RPMI medium. When cell proliferation $\% 70$ in cell culture plates, medium was changed with serum free RPMI for 16 hours. The cells were exposed to various concentrations $(0,31,62$, $125,250,500 \mu \mathrm{M})$ of complexes with serum free medium for $24 \mathrm{~h}$. The untreated cells were used as control [39].

\section{MTT Assay (Cell Viability)}

Acoording to MTT assay; Cell culture media replaced with $100 \mu \mathrm{l}$ MTT (Gibco, USA) solution (mg/ml) to each well. The culture was incubated for $1 \mathrm{~h}$ until living cell stanied. We checked with microscope and discarded MTT solutio. We was added $100 \mu$ dimethyl sulfoxide (DMSO) and measured at $570 \mathrm{~nm}$ by a plate reader (Biotek, USA) [39].

Statistical analysis: MTT results were analyzed for non-normally distributed Mann-Whitney U test. We has analyzed tratment groups compared to the control group (DMSO including to high concentration). According to finding data, $p$ values $<0.05$ were noted to be significant. Prism 6 program used for statistical analysis (GraphPad Software, Inc, San Diego, USA).

\section{Conclusion}

A new series of ternary samarium (III) complexes with diketone structures including various groups has been successfully synthesized and characterized. The complexes showed the ligand-based emission ${ }^{1} \mathrm{~S}_{1}$ $\rightarrow{ }^{1} S_{0}$ in the range of 350-550 $\mathrm{nm}$. The $\beta$-diketone ligands caused an antenna effect and complexes exhibited Sm(III) based f-f transitions. The HTB-54 and BEAS-2B cell lines were used to test their antiproliferative activities in vitro. According to results, [Sm(MPBP-1,3PPon) $\left.\left.{ }_{3}\right] \cdot \mathrm{H}_{2} \mathrm{O}\right)\left(\mathrm{IC}_{50}: 11.05 \mu \mathrm{M}\right)$ and [Sm(BMP-1,3PPon) $\left.{ }_{3}\right] \cdot 2 \mathrm{H}_{2} \mathrm{O}$ compounds stronger activity against the HTB-54 cancer cell line. But only one of these compounds shows the potential drug, which is compound [Sm(MPBP-1,3PPon) $\left.\left.{ }_{3}\right] \cdot \mathrm{H}_{2} \mathrm{O}\right)$. Because compound [Sm(MPBP-1,3PPon) $\left.{ }_{3}\right] \cdot \mathrm{H}_{2} \mathrm{O}$ ) has an inhibitory effect on the cancer cell $\mathrm{HTB}^{1}-54$, while it is not effective on the healthy cell BEAS2B. 


\section{Declarations}

\section{Acknowledgment}

The authors thank TÜBITAK (Project no: 115Z840) for the financial support. And also the authors thank Gaziantep University Respiratory Diseases and Surgery Application and Research Center.

Author contributions Methodology, data curation, analyses and synthesis, AOS; anticancer study DTK; Photoluminescense study, AK; Conceptualization and supervision, MS.

\section{Compliance with ethical standards}

Conflict of interest The authors declare no competing interests.

\section{References}

1. Drozdov A, Kuzmina N (2013) 2.19-Volatile compounds of lanthanides. In: Reedijk J, Poeppelmeier K (eds) Comprehensive Inorganic Chemistry II (Second Edition), vol 2. Elsevier, Amsterdam, pp 511534. https://doi.org/10.1016/B978-0-08-097774-4.00223-0

2. Binnemans K (2009) Lanthanide-Based Luminescent Hybrid Materials. Chem Rev 109:4283-4374. https://doi.org/10.1021/cr8003983

3. de Bettencourt-Dias A (2007) Lanthanide-based emitting materials in light-emitting diodes. Dalton Trans 22:2241. https://doi.org/10.1039/B702341C

4. Eliseeva SV, Buzli JCG (2011) Rare earths: jewels for functional materials of the future. New J Chem 35:1165-1176. https://doi.org/10.1039/CONJ00969E

5. Walsh BM, Barnes NP, Petros M, Yu J, Singh UN (2004) Spectroscopy and modeling of solid state lanthanide lasers: Application to trivalent $\mathrm{Tm}^{3+}$ and $\mathrm{Ho}^{3+}$ in $\mathrm{YLiF}_{4}$ and $\mathrm{LuLiF}_{4}$. J Appl Phys 95:32553271. https://doi.org/10.1063/1.1649808

6. Sun LN, Zhang HJ, Meng QG, Liu FY et al (2005) Near-Infrared Luminescent Hybrid Materials Doped with Lanthanide ( $L n)$ Complexes $(L n=N d, Y b)$ and Their Possible Laser Application. J Phys Chem B 109:6174-6182. https://doi.org/10.1021/jp044591h

7. Wang YP, Dai TY, Wu J, Ju YL, Yao BQ (2018) A Q-switched Ho:YAG laser with double antimisalignment corner cubespumped by a diode-pumped Tm:YLF laser. Infrared Phys Technol 91:811. https://doi.org/10.1016/j.infrared.2018.03.020

8. Wang H, Zhao D, Cui Y, Yang Y, Qian G (2017) A Eu/Tb-mixed MOF for luminescent high-temperature sensing. J Solid State Chem 246:341-345. https://doi.org/10.1016/j.jssc.2016.12.003

9. Zhang Y, Yuan S, Day G, Wang X, Yang X, Zhou HC (2018) Luminescent sensors based on metalorganic frameworks. Coord Chem Rev 354:28-45. https://doi.org/10.1016/j.ccr.2017.06.007

10. Chen RX, Gao T, Sun WB, Li HF, Wu YH et al (2015) Salen homonuclear and heteronuclear lanthanide(III) complexes with near-infrared (NIR) luminescence. Inorg Chem Commun 56:79-82. 
https://doi.org/10.1016/j.inoche.2015.03.053

11. Zhang KY, Yu Q, Wei H, Liu S, Zhao Q, Huang W (2018) Long-Lived Emissive Probes for TimeResolved Photoluminescence Bioimaging and Biosensing. Chem Rev 118:1770-1839. https://doi.org/10.1021/acs.chemrev.7b00425

12. Zheng W, Tu D, Huang P, Zhou S, Chen Z, Chen X (2015) Time-resolved luminescent biosensing based on inorganic lanthanide-doped nanoprobes. Chem Commun 51:4129-4143. https://doi.org/10.1039/C4CC10432C

13. Hagan AK, Zuchner T (2011) Lanthanide-based time-resolved luminescence immunoassays. Anal Bioanal Chem 400:2847-2864. https://doi.org/10.1007/s00216-011-5047-7

14. Chen T, Hong R, Magda D, Bieniarz C, Morrison L, Miller LW (2017) Time gated luminescence imaging of immunolabeled human tissues. Anal Chem 89:12713-12719.

https://doi.org/10.1021/acs.analchem.7b02734

15. Gai S, Li C, Yang P, Lin J (2014) Recent Progress in Rare Earth Micro/Nanocrystals: Soft Chemical Synthesis, Luminescent Properties, and Biomedical Applications. Chem Rev 114:2343-2389. https://doi.org/10.1021/cr4001594

16. Placide V, Bui AT, Grichine A, Duperray A, Pitrat D, Andraud C, Maury O (2015) Two-photon multiplexing bio-imaging using a combination of Eu- and Tb-bioprobes. Dalton Trans 44:4918-4924. https://doi.org/10.1039/C4DT03115F

17. Carlos LD, Ferreira RAS, de Zea Bermudez V, Julián-López B, Escribano P (2011) Progress on lanthanide-based organic-inorganic hybrid phosphors. 40:536-549. https://doi.org/10.1039/COCS00069H. 2

18. Latendresse TP, Bhuvanesh NS, Nippe M (2017) Slow Magnetic Relaxation in a Lanthanide[1]Metallocenophane Complex. J Am Chem Soc 139:8058-8061. https://doi.org/10.1021/jacs.7b01499

19. Harriman KLM, Brosmer JL, Ungur L, Diaconescu PL, Murugesu M (2017) Pursuit of Record Breaking Energy Barriers: A Study of Magnetic Axiality in Diamide Ligated Dy III Single-Molecule Magnets. J Am Chem Soc 139:1420-1423. https://doi.org/10.1021/jacs.6b12374

20. Ge JY, Wang HY, Su J, Li J, Wang BL, Zhang YQ, Zuo JL (2018) Modulating the Magnetic Interaction in New Triple-Decker Dysprosium(III) Single-Molecule Magnets. Inorg Chem 57:1408-1416. https://doi.org/10.1021/acs.inorgchem.7b02824

21. Wang HS, Long QQ, Yin CL, Xu ZW, Pan ZQ (2018) Syntheses, crystal structures and magnetic properties of sandglass Dy ${ }^{\mathrm{III}}{ }_{9}$ and irregular tetrahedron Dy ${ }^{\mathrm{III}}{ }_{4}$ complexes. Polyhedron 141:69-76. https://doi.org/10.1016/j.poly.2017.11.025

22. Woodruff DN, Winpenny REP, Layfield RA (2013) Lanthanide Single-Molecule Magnets. Chem Rev 113:5110-5148. https://doi.org/10.1021/cr400018q

23. Peng D, Yin L, Hu P, Li B, Ouyang ZW, Zhuang GL, Wang Z (2018) Series of Highly Stable LanthanideOrganic Frameworks Constructed by a Bifunctional Linker: Synthesis, Crystal Structures, and 
Magnetic and Luminescence Properties. Inorg Chem 57:2577-2583.

https://doi.org/10.1021/acs.inorgchem.7b02969

24. Li LJ, Li YK, Ren Z, Luo YK, Lin X, He M, Tao Q, Zhu ZW, Cao GH, Xu ZA (2008) Superconductivity above $50 \mathrm{~K}$ in $\mathrm{Tb}_{1-\mathrm{x}} \mathrm{Th}_{\mathrm{x}} \mathrm{FeAsO}$. Phys Rev B 78:132506. 10.1103/PhysRevB.78.132506

25. Kishio K, Kitazawa K, Hasegawa T, Aoki M, Fueki K, Uchida S, Tanaka S (1987) Effect of Lanthanide Ion Substitutions for Lanthanum Sites on Superconductivity of $\left(\mathrm{La}_{1-x} \mathrm{Sr}_{x}\right)_{2} \mathrm{CuO}_{4-\delta}$. Jpn J Appl Phys 26(4A):L391-L393. https://doi.org/10.1143/JJAP.26.L391

26. Pecharsky VK, Miller LL, Gschneidner KA (1998) Low-temperature behavior of two ternary lanthanide nickel carbides: Superconducting $\mathrm{LaNiC}_{2}$ and magnetic CeNiC 2 . Phys. Rev. B. ;58:497-502. https://doi.org/10.1103/PhysRevB.58.497

27. Ren Z, Zhu Z, Jiang S, Xu X, Tao Q, Wang C, Feng C, Cao G, Xu Z (2008) Antiferromagnetic transition in $\mathrm{EuFe}_{2} \mathrm{As}_{2}$ : A possible parent compound for superconductors. Phys Rev B 78:052501. https://doi.org/10.1103/PhysRevB.78.052501

28. Wu SQ, Wang ZC, He CY, Tang ZT, Liu Y, Cao GH (2017) Superconductivity at 33-37 K in $\mathrm{ALn}_{2} \mathrm{Fe}_{4} \mathrm{As}_{4} \mathrm{O}_{2}$ ( $\mathrm{A}=\mathrm{Kand} \mathrm{Cs}$; Ln=lanthanides). Phys Rev Mater 1:044804. https://doi.org/10.1103/PhysRevMaterials.1.044804

29. Fang Y, Yazici D, Jeon I, Maple MB (2017) High-pressure effects on nonfluorinated $B \mathbf{S}_{2}$-based superconductors $\mathrm{La}_{1-\mathrm{x}} \mathrm{M}_{\mathrm{xOBis2}}$ (M=Ti and Th). Phys Rev B 96:214505. https://doi.org/10.1103/PhysRevB.96.214505

30. Li CR, Liu ZC, Wang BD, Li TR, Yang ZY Synthesis and fluorescence properties of Sm-2-oxo-quinoline3-carbaldehyde-isonicotinyl hydrazone decorated with 1,10-phenanthroline.Synth. Met. 2015:209:273-278. https://doi.org/10.1016/j.synthmet.2015.08.009

31. Hufner S (1978) Optical Spectra of Transparent Rare Earth Compounds. Academic, New York

32. Ilmi R, Iftikhar K (2017) Synthesis and photoluminescence properties of pink luminescent heteroleptic Sm(III) complexes; the role of DMSO in transforming the inner coordination sphere and on photophysical properties. Sparkle/RM1 calculation. Polyhedron 127:191-202. https://doi.org/10.1016/j.poly.2017.01.035

33. Dossing A (2005) Luminescence from lanthanide (3+) ions in solution. Eur J Inorg Chem 8:14251434. https://doi.org/10.1002/ejic.200401043

34. Cancer - World Health Organization (2019) https://www.who.int/news-room/factsheets/detail/cancer. Accessed March 21,

35. Collins LG, Haines C, Perkel R, Enck RE (2007) Lung cancer: diagnosis and management. Am Fam Physician. ;75(1):56-63. PMID: 17225705

36. Miller RP, Tadagavadi RK, Ramesh G, Reeves WB (2010) Mechanisms of Cisplatin nephrotoxicity. Toxins (Basel) 11:2490-2518. 10.3390/toxins2112490

37. Yaegashi A, Yoshida K, Suzuki N, Shimada I, Tani Y, Saijo Y, Toyama A (2019) A case of severe hepatotoxicity induced by cisplatin and 5-fluorouracil. Int Cancer Conf J 9(1):24-27. 
10.1007/s13691-019-00394-2

38. Tasdemir D et al (2015) Synthesis, molecular modeling, and biological evaluation of novel chiral thiosemicarbazone derivatives as potent anticancer agents. Chirality 27(2):177-188.

$10.1002 /$ chir.22408

39. Sarıoğlu AO, Yalçın ŞP, Ceylan Ü, Aygün M, Kırpık H, Sönmez M (2020) Photoluminescence properties of samarium(III)-based complexes: Synthesis, characterization and single crystal X-ray. J Lumin 227:117537. https://doi.org/10.1016/j.jlumin.2020.117537

40. Sarıoğlu AO, Sönmez M, Yalçın ŞP, Ceylan Ü, Aygün M (2019) Eu(III) and Tb(III) complexes of 1,3bis(4-chlorophenyl)-1,3-propanedione combined with phenanthroline ligand: synthesis, structural characterization, and thermogravimetric studies. J Coord Chem 72(7):5.

10.1080/00958972.2019.1593387

41. Bhat SA, Iftikhar K (2020) Samarium complexes with fluorinated $\beta$-diketone and heterocyclic Lewis bases as UV light converters. Dyes Pigm 179:108383. https://doi.org/10.1016/j.dyepig.2020.108383

42. Akbas E, Ekin S, Ergan E, Karakus Y, Synthesis (2018) DFT calculations, spectroscopy andin vitroantioxidantactivity studies on 4-hydroxyphenyl substituted thiopyrimidinederivatives. J Mol Struct 1174:177-183. https://doi.org/10.1016/j.molstruc.2018.02.080

43. Ilmi R, Iftikhar K (2017) Synthesis and photoluminescence properties of pink luminescent heteroleptic Sm(III) complexes; the role of DMSO in transforming the inner coordination sphere and on photophysical properties. Sparkle/RM1 calculation. Polyhedron 127:191-202. https://doi.org/10.1016/j.poly.2017.01.035

44. Bhat SA, Iftikhar K (2020) Samarium complexes with fluorinated $\beta$-diketone and heterocyclic Lewis bases as UV light converters. Dyes Pigm 179:108383. https://doi.org/10.1016/j.dyepig.2020.108383

45. Sizov VS, Komissar DA, Metlina DA, Aminev DF et al (2020) Effect of ancillary ligands on visible and NIR luminescence of $\mathrm{Sm}^{3+} \beta$-diketonate complexes. Spectrochim Acta A Mol Biomol Spectrosc 225:117503. https://doi.org/10.1016/j.saa.2019.117503

46. Taydakov IV, Korshunov VM, Belousov YA, Nelyubina YV et al (2020) Synthesis, crystal structure and photophysical properties of mixed-ligand lanthanide complexes with 1,3-diketonates bearing pyrazole moieties and 1,10-phenanthroline. Inorganica Chim Acta 513:119922. https://doi.org/10.1016/j.ica.2020.119922

47. Tăbăcaru A, Dediu AVB, Dinică RM, Carac G, Basliu V et al (2020) Biological properties of a new mixed lanthanide(III) complex incorporating a dypiridinium ylide. Inorganica Chim Acta 506:119517. https://doi.org/10.1016/j.ica.2020.119517

48. Kawai H, Zhao C, Tsuruoka S, Yoshida T, Hasegawa Y, Kawai T (2009) Emission properties of Sm(III) complexes having remarkably deep-red emission band. J Alloys Compd 488(2):612-614. https://doi.org/10.1016/j.jallcom.2008.09.091

49. 49. Kawai H, Zhao C, Tsuruoka S, Yoshida T, Hasegawa Y, Kawai T. Emission properties of Sm(III) complexes having remarkably deep-red emission band. J. Alloys Compd. 2009;488(2):612-614. https://doi.org/10.1016/j.jallcom.2008.09.091 
Figures

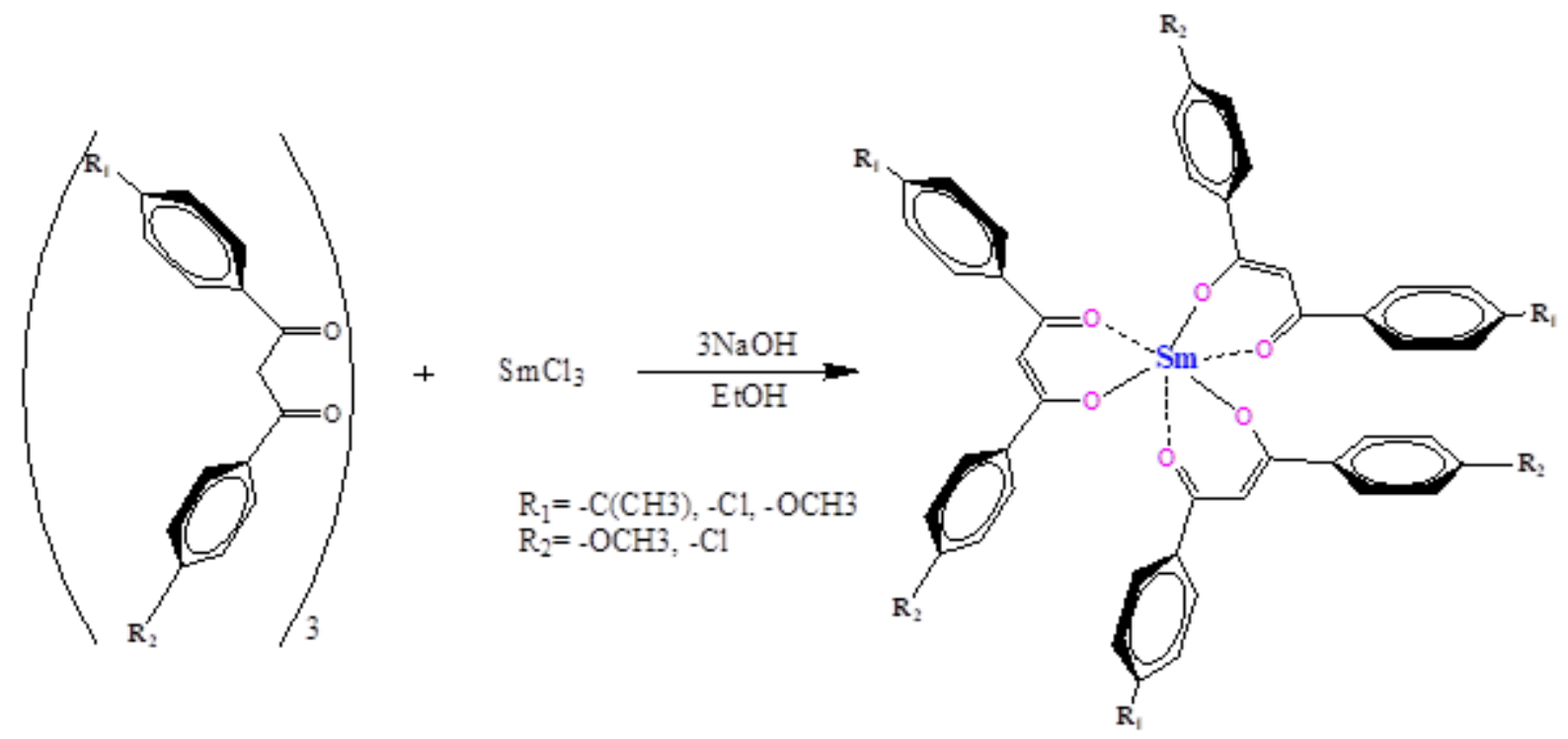

Figure 1

Synthetic scheme of the Samarium complexes 


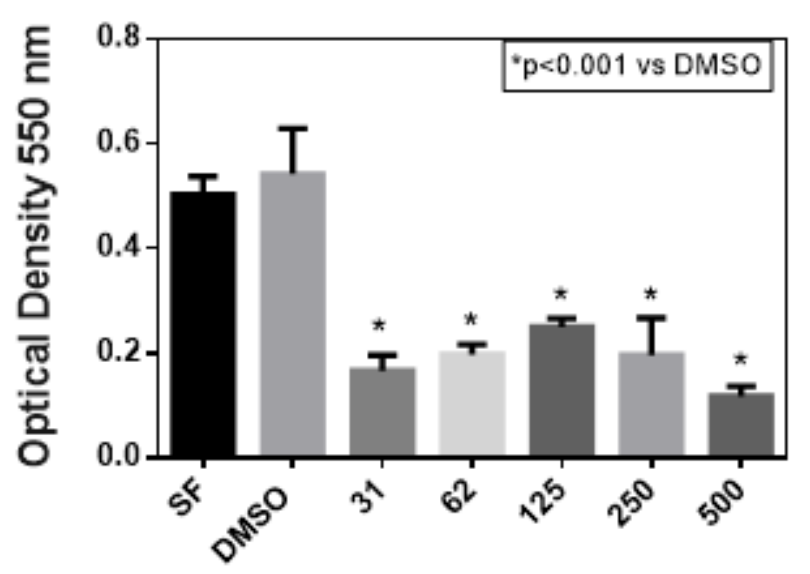

[Sm(MPBP-1,3PPon)3]·H2O) ( $\mu$ M)

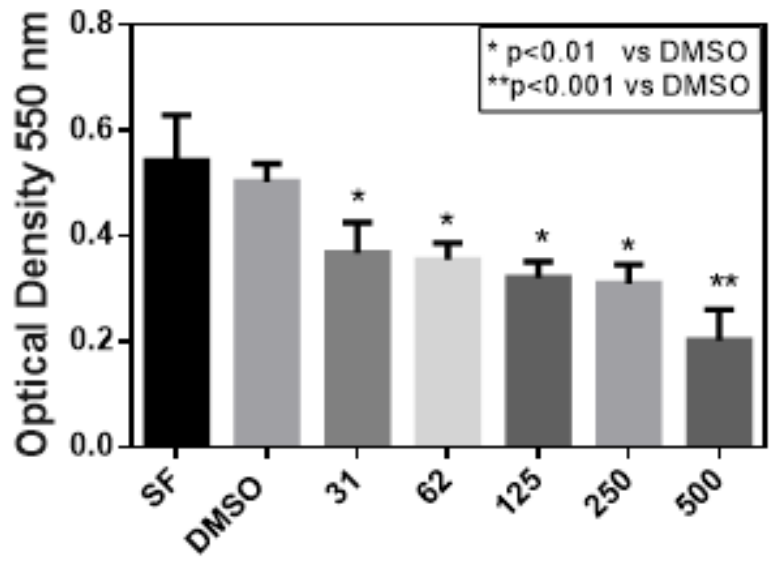

[Sm(BMP-1,3PPon)3]·2H2O $(\mu \mathrm{M})$

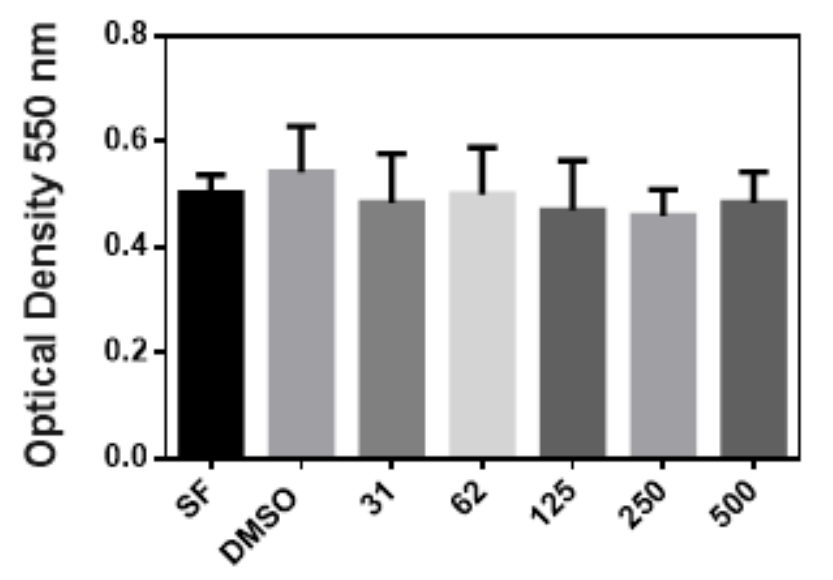

[Sm(BCP-1,3PPon)3]·H2O $(\mu \mathrm{M})$

Figure 2

Cell viability of complexes: Effect of complexes against HTB54 cell line 


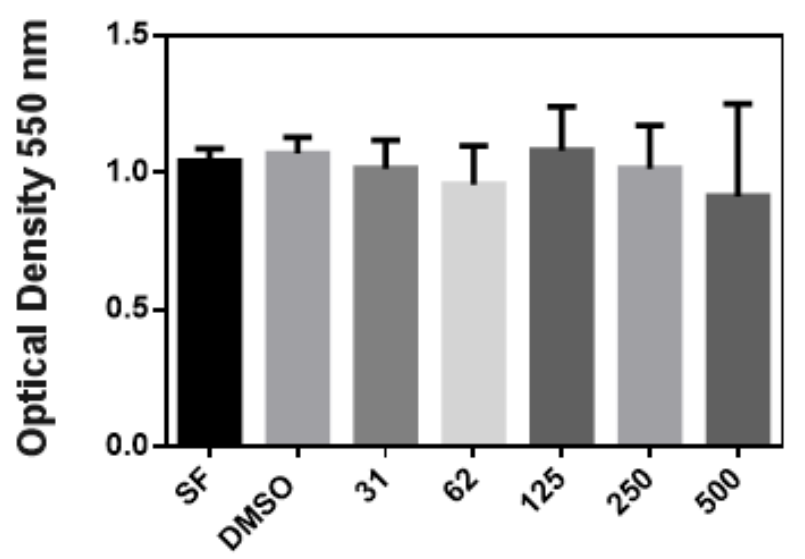

[Sm(MPBP-1,3PPon)3]·H2O) $(\mu \mathrm{M})$

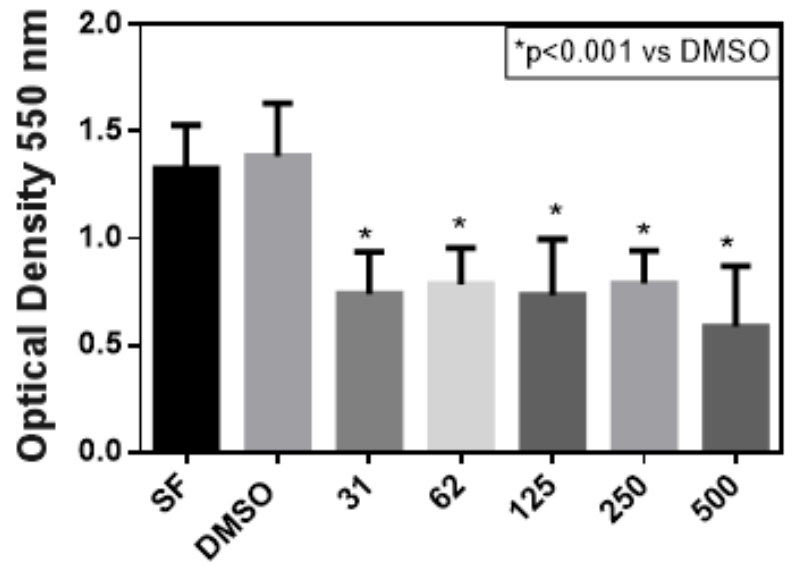

[Sm(BMP-1,3PPon)3]·2H2O $(\mu \mathrm{M})$

Figure 3

Cell viability of complexes: Effect of complexes against BEAS-2B cell line

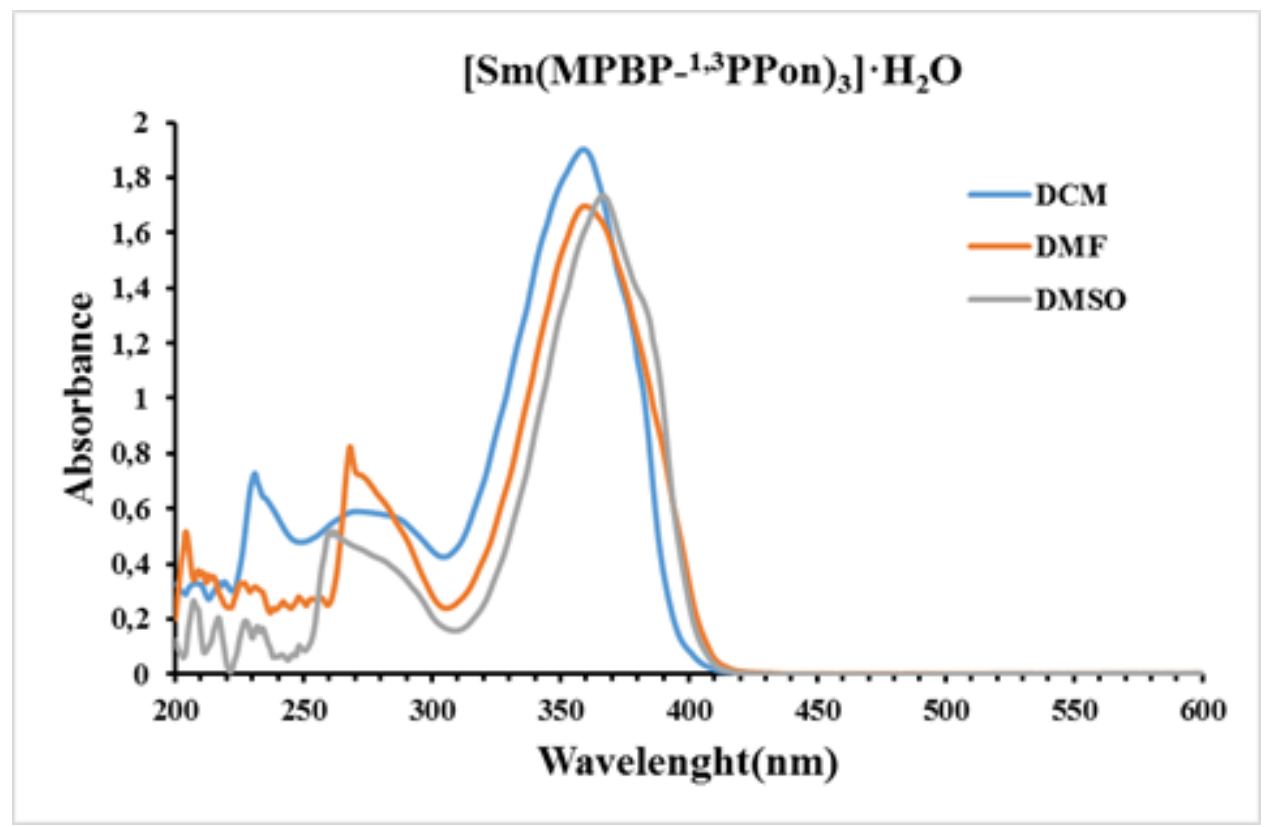

Figure 4

UV-Vis spectra of [Sm(MPBP-1,3PPon) $\left.{ }_{3}\right] \cdot \mathrm{H}_{2} \mathrm{O}$ in DCM, DMF, DMSO. 


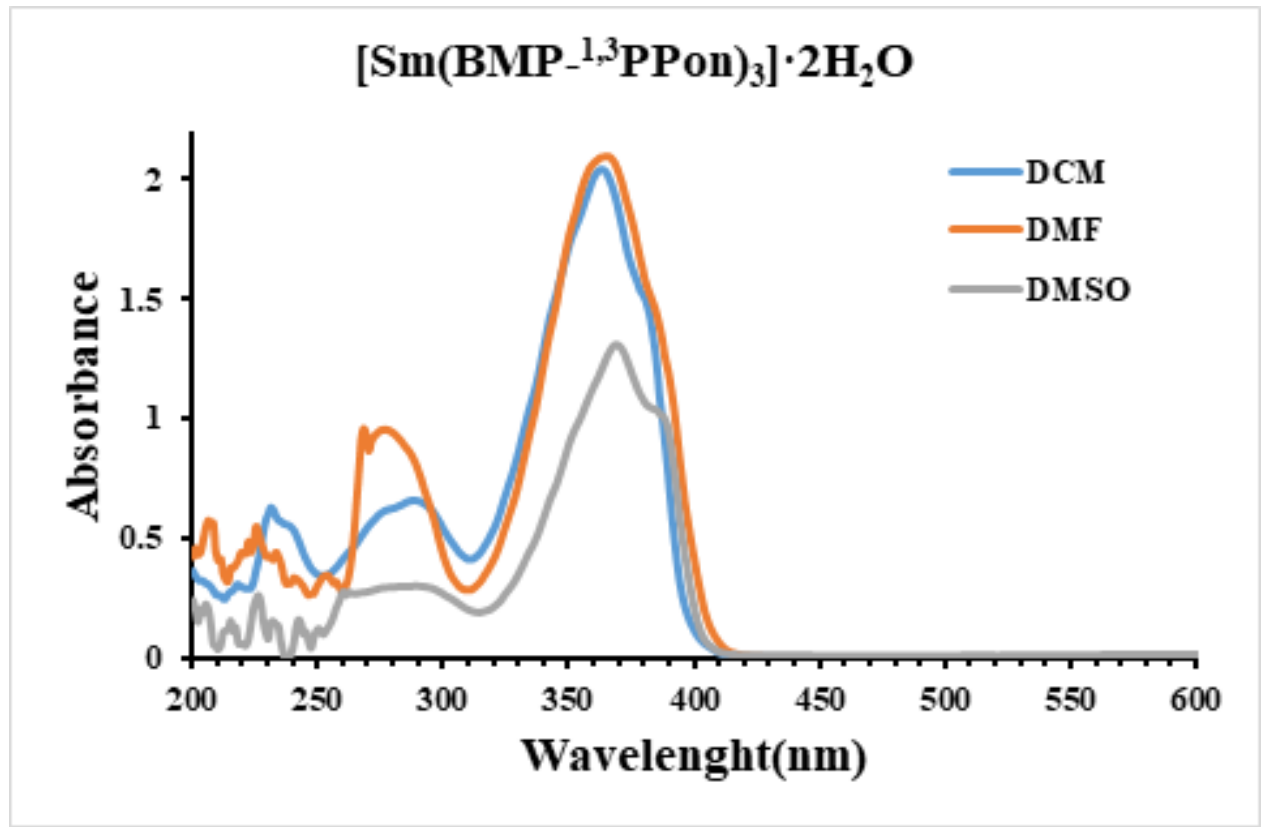

Figure 5

UV-Vis spectra of [Sm(BMP- ${ }^{1,3}$ PPon $\left.)_{3}\right] \cdot 2 \mathrm{H}_{2} \mathrm{O}$ in DCM, DMF, DMSO.

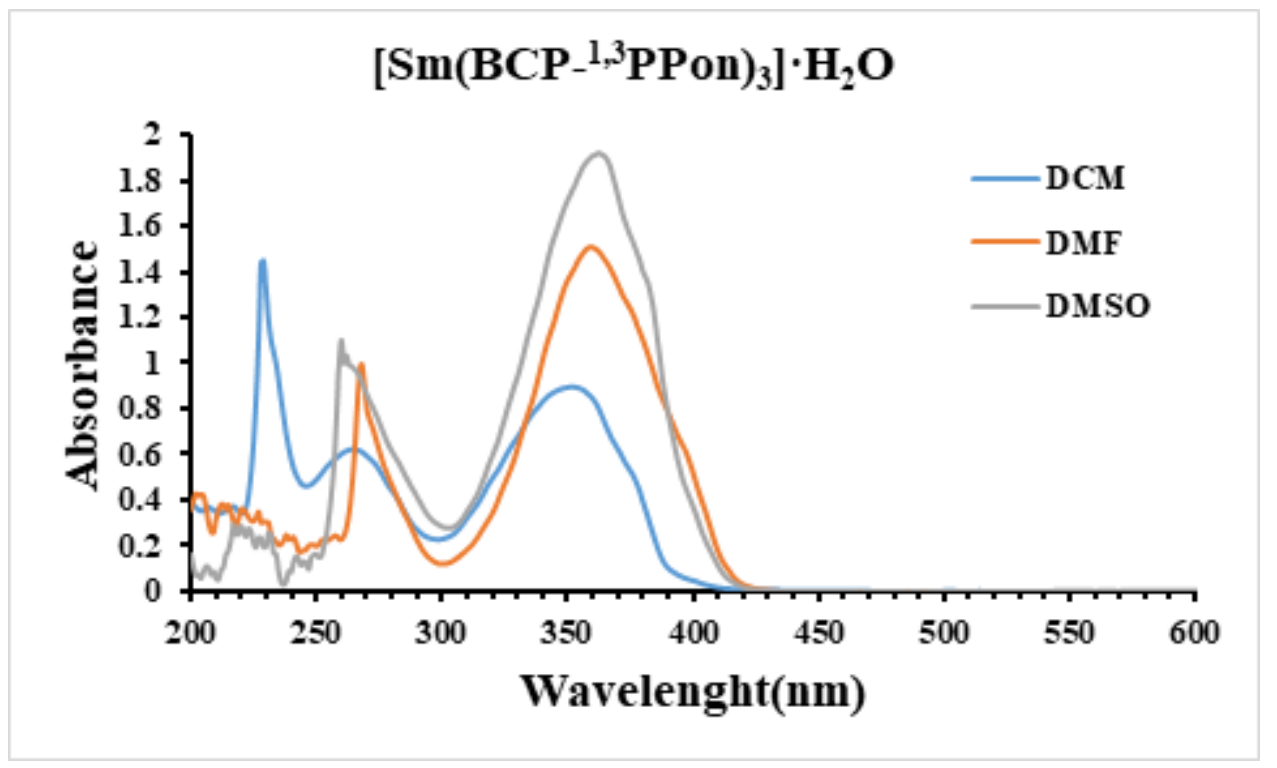

Figure 6

UV-Vis spectra of $\left[\mathrm{Sm}\left(\mathrm{BCP}^{1}{ }^{1,3} \mathrm{PPon}\right)_{3}\right] \cdot \mathrm{H}_{2} \mathrm{O}$ in DCM, DMF, DMSO. 


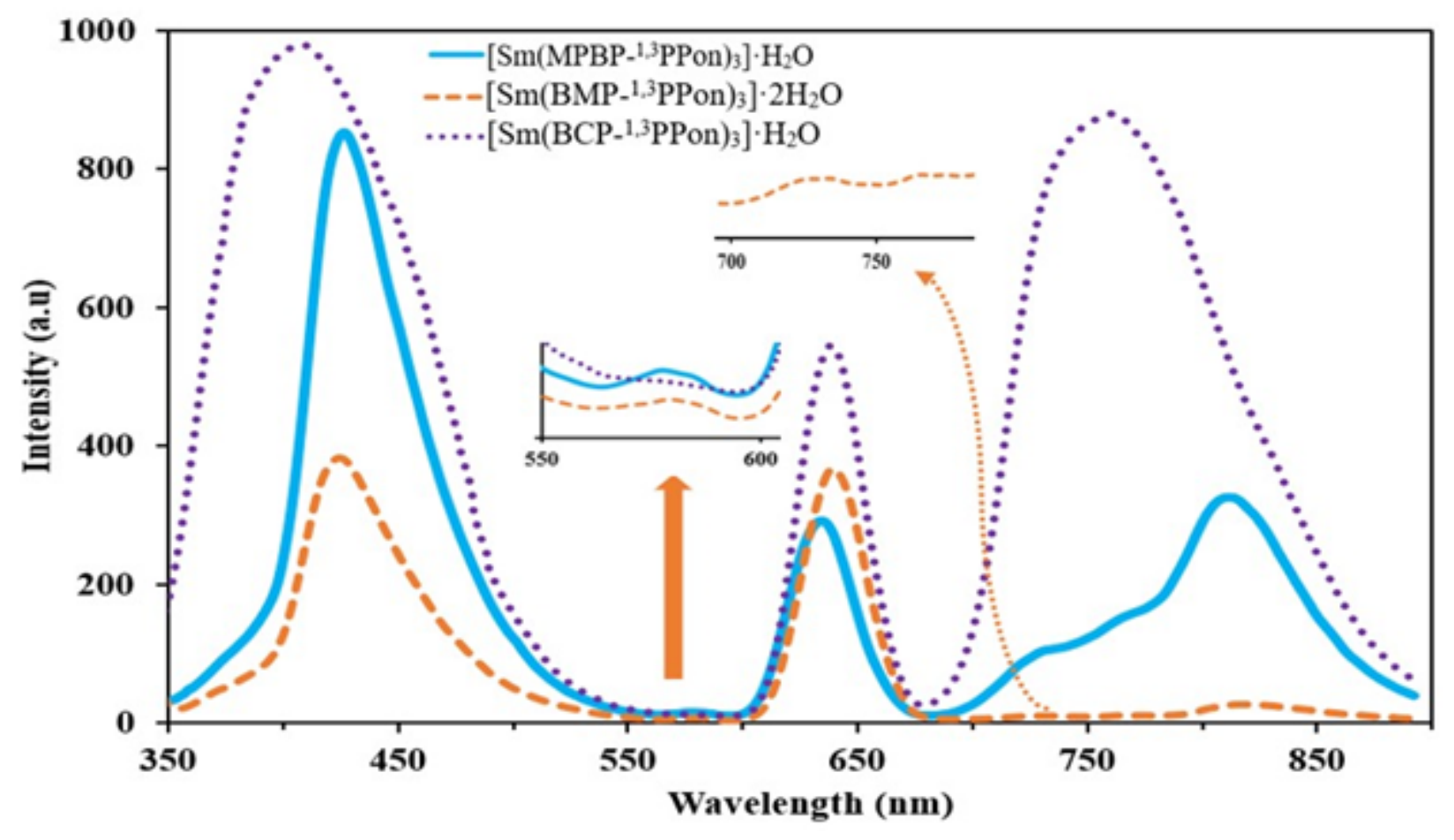

Figure 7

Emission spectra of the complexes in DMF $\left.\left.\left(10^{-5} \mathrm{M}\right)\left(\lambda_{\text {exc }}: 308 \text { for [Sm(MPBP-1,3PPon) }\right)_{3}\right] \cdot \mathrm{H}_{2} \mathrm{O}\right), 310$ for $\left[\mathrm{Sm}\left(\mathrm{BMP}^{1}{ }^{1,3} \mathrm{PPon}\right)_{3}\right] \cdot 2 \mathrm{H}_{2} \mathrm{O}$ and $\left.\left[\mathrm{Sm}\left(\mathrm{BCP}^{1}{ }^{1,3} \mathrm{PPon}\right)_{3}\right] \cdot \mathrm{H}_{2} \mathrm{O}\right)$

\section{Supplementary Files}

This is a list of supplementary files associated with this preprint. Click to download.

- GA.png

- AOSetalSupplementarymaterials.docx 